\title{
ASSESSMENT OF YOUNG LEARNERS IN THE PRE-LITERACY PERIOD IN SERBIA ${ }^{2}$
}

\begin{abstract}
Given the fact that English is an obligatory subject in Serbian schools since the first grade, many parents opt for an early start and enroll their children in English classes while they are still in kindergarten, before they can actually read or write. Another context in which young learners learn English in Serbia are the first two grades of primary school, which are also considered to belong to the pre-literacy period because children learn the Latin alphabet only in the second semester of the second grade. For those reasons pupils in Serbia do not read or write in English until the age of 9, so the question is how the teacher can implement assessment in the pre-literacy period. Relying on informal interviews with 15 teachers, this paper intends to investigate how assessment is done with very young learners in the pre-literacy period in private and state-owned primary schools and to present a solution based on the competences that children in this age group already possess, as well as on the teaching and learning aspects which are of great value for the improvement of children's English language competence.
\end{abstract}

KEYWORDS: young learners, pre-literacy period, assessment, formative assessment, summative assessment.

\footnotetext{
radic.bojanic@ff.uns.ac.rs; jagoda.topalov@ff.uns.ac.rs

2 The paper is the result of research conducted within project № 178002 Languages and cultures across time and space funded by the Ministry of Education, Science and Technological Development of the Republic of Serbia.

This paper was submitted on February 20, 2017 and accepted for publication at the meeting of the Editorial Board held on September 19, 2017.
} 
As of a decade ago English has been an obligatory subject in Serbian schools since the first grade because of the intention of the Ministry of Education to align the curricula with the recommendations of the Council of Europe and the Common European Framework of Reference. Namely, the long-term plan is to enable children to acquire two foreign languages in the course of their primary and secondary education, the first one being English due to its widespread usage, and the second one being one of the world languages (German, French, Italian, Russian, Spanish, depending on the school), which is taught from the fifth grade onwards.

Because of this and, even more, because of the status of the English language in the world today, many parents opt for an early start and enrol their children in English classes while they are still in kindergarten. In some kindergartens this option is institutionally supported, which means that kindergarten teachers are also trained to teach elementary English to children, but this is not a very frequent case. Furthermore, in Serbia there are also two more options for early English language acquisition: (1) an English teacher comes to the kindergarten and teaches children English; (2) parents enrol the child to a private school of foreign languages, where he/she attends English classes. However, the question is in how many of these contexts we find any form of assessment, what its purpose is and how it is done.

Another context in which young learners learn English in Serbia are the first two grades of primary school, which are also considered to belong to the pre-literacy period because of the fact that in Serbian schools children learn the Latin alphabet only in the second semester of the second grade. For those reasons pupils do not read or write in English until the age of 9, which again begs the question of how assessment is done in this educational context as well. The aim of this paper, therefore, is to provide answers to the following questions:

- Is assessment of English language competence done with young learners in the pre-literacy period in schools in Serbia at all?

- If yes, how is it done (which instruments are used and according to which criteria is it done)?

- To what purpose is assessment done in the said context? 
- Are there any differences between the manner and purpose of assessing pupils in private and state-owned schools?

In order to answer these research questions an informal interview was organized with 15 teachers who work with very young learners either in private or state schools and the results of the investigation are presented in the paper along with a critical view of the situation and suggestions for the improvement.

ASSESSMENT IN ELT

Two opposing and complementary types of assessment most often employed in ELT are formative and summative. The former one is defined as "informal evaluation which teachers implement on an ongoing basis to make sure that students are mastering the concepts and the target language items which they explore in class" (Gordon, 2007, p. 23). On the other hand, summative assessment is used "at the end of an instructional unit or academic year" (Gordon, 2007, p. 24) as "a judgment which encapsulates all the evidence up to a given point" (Taras, 2005, p. 468). It is apparent from the definitions that these two types of assessment rely on different instruments and have different purposes in the classroom context.

In formal educational contexts summative assessment is extremely frequent and we could say that it is the primary source of grades and student ranking in various language courses. Even though, according to a variety of experts (e.g. Alderson et al. 1995; Henning, 1987; Hughes 1989), it provides an objective measurement of the students' acquired knowledge, many complaints are also heard with respect to the accompanying backwash effect (see e.g. Prodromou, 1995) it has on the teaching process. Namely, "[M]any teachers, trapped in an examination preparation cycle, feel that communicative and humanistic methodologies are luxuries they cannot afford" (Prodromou, 1995, p. 13) so "[S]ound teaching practices are often sacrificed in an anxious attempt to 'cover' the examination syllabus, and to keep ahead of the competition" (Prodromou, 1995, p. 13). In other words, classes are reduced to the teaching of what is going to be tested, not of what students will or might need in future when they use the foreign language they are learning. 
Formative assessment, on the other hand, functions in an informal way and yet provides essential and precious feedback to teachers themselves, to students and parents, and to other teachers. The results of formative assessment are used "to inform on-going learning and teaching by providing immediate feedback" (Cameron, 2001, p. 222). In comparison with summative assessment, formative assessment seems to be less influenced by backwash. Cameron (2001, p. 215) herself says that "[I]t would seem reasonable to require assessment to serve teaching, by providing feedback on pupils' learning that would make the next teaching event more effective, in a positive, upwards direction. Teaching and learning should dictate the form and timing of assessment", which coincides to a great extent with the purpose and characteristics of formative assessment. Another characteristic of this type of assessment frequently mentioned in the literature (e.g. Shaaban, 2001; Yildirim \& Orsdemir, 2013) is that it has a positive effect on the pupils' emotions thus contributing to the positive classroom atmosphere in which the affective filter is low. Smith (1996) thus claims that "traditional classroom testing procedures can cause children a great deal of anxiety that affects their language learning as well as their self-image" (quoted in Shaaban, 2001, pp. 17-18), which is another argument to speak in favor of formative assessment, especially with young learners.

When it comes to instruments used in both types of assessment, in summative assessment we usually find teacher-made pen-and-paper tests "testing single items of vocabulary and grammar through single sentences" (Cameron, 2001, p. 217). Furthermore, summative assessment usually focuses on achievement measuring the progress of pupils from one teaching point to another (per unit, per semester, etc.), and can be either criterion-referenced (the pupils' performance is matched against an expected response on an item, or a set of descriptors or a scale is used, see Cameron, 2001, p. 223) or norm-referenced (a comparison of individual achievements in the group). In the context of the age group under scrutiny in this paper we can conclude that the potential of this kind of assessment is diminished because of the fact that very young pupils can neither read nor write and are, therefore, not able to take pen-and-paper tests that rely on textual information, which only leaves room for a variety of tasks that employ images. 
Conversely, the instruments used in formative assessment are to a greater extent based on continuous student engagement and range from personal journals and portfolios through peer- and self-assessment to student-teacher conferences and observations (for more details on each of these assessment instruments see Shaaban, 2001). These alternative forms of assessment, as Shaaban (2001) calls them, are mainly used to provide feedback both to the teacher and to the student, not to yield grades or rankings. With respect to the pre-literacy period, we can conclude that again the majority of the listed instruments cannot be applied because the pupils cannot read or write. In addition, most of these formative assessment procedures require a certain level of metacognition in the student, who should be able to choose his/her most representative works for the portfolio, or write in the journal about the problems he/she encounters when studying the foreign language, or report on these problems in self-assessment sheets. Very young learners simply do not have this level of metacognition developed yet, so the scope of alternative assessment instruments is narrowed down by this fact as it is narrowed down by the fact that they can still neither read nor write.

Therefore, the only possible formative assessment instrument with very young learners is observation, which allows the teachers to "learn the extent of their students' strategic competence and ascertain what type of help would benefit language learners" (Gordon, 2007, p. 209). However, observation must be based on objective criteria which are used consistently throughout the academic year, otherwise it is neither effective nor informative. In case the objective and pre-defined set of criteria is missing, observation will in most cases be arbitrary and subjective.

Unlike some ways of assessing (portfolios, self-assessment, peer-assessment, journals) which are based on a personal response, observations are performance-based (Shaaban, 2001; Yildirim \& Orsdemir, 2013). The pupils are, thus, assessed while performing authentic tasks that rely on oral (and written, where possible) skills, pair and group work, or problem-solving (Shaaban, 2001, p. 18). Cameron (2001, p. 231) clearly states that "[o]bservation is one of the most useful assessment techniques to use with children because it does not disturb the children and allows them to be assessed in the process of ordinary classroom activities". That is, in any case, what every teacher practically does all the time: he/she observes their pupils and adjusts the teaching process, the input, 
the materials, the approach, etc. Cameron (2001, p. 231) sums up this process as "observe - notice - adjust teaching" and rightly claims that the same approach can be pre-planned for assessment purposes:

The teacher selects the focus of assessment and decides in advance that she or he will observe the children during the next lesson to assess how well they have learnt that particular aspect of the language. 'Observation', as a metaphor to describe how we collect this type of assessment information, builds on the idea of having a 'focus' and emphasis that we have to do much more than just 'look' at what pupils say or do. Rather, we need to look very carefully at the particular aspect of language that we are concentrating on, and use our experience and knowledge about language and learning to guide us in what we look for and how we interpret what we see. (Cameron, 2001, p. 231)

In such cases scoring is done holistically (Shohamy, 1995) and teachers rely on previously set and established standards. As said earlier, such standards and clear descriptions of how to assess particular tasks and performances diminish or even eliminate arbitrariness and subjectivity. At the same time, they are immensely helpful in terms of objective and useful feedback which will in turn inform the teaching and learning process and thus improve it.

Which of the assessment techniques and instruments are used in assessing very young learners in the pre-literacy period in private and state schools in Serbia, and whether the situation matches the ideal and proposed framework will be investigated in the remainder of the paper.

\section{RESEARCH}

Intending to investigate how assessment is done in the Serbian educational system (both the private and state sector) with pupils who still cannot read or write, we adopted a qualitative research design focusing on grounded theory, as our goal was to derive a general understanding of the process grounded in the view of teachers working with pre-literacy children. In the paper, we aim to provide answers to the following questions: (1) if assessment of English language competence is done with very young learners in the pre-literacy period in schools in Serbia at all; (2) if yes, which instruments are used and according to which criteria it is done; 
(3) what the purpose of the assessment in the pre-literacy period is; and (4) if there are any differences between the manner and purpose of assessing pupils in private and state-owned schools.

We rely on informal interviews conducted with 15 teachers who work either in private schools $(\mathrm{N}=7)$ or state schools $(\mathrm{N}=8)$ and who teach children aged 5-8. Based on the theoretical and practical underpinnings of a qualitative inquiry (Corbin \& Strauss, 1990, p. 8), representativeness and consistency of the sampling is achieved, as we sampled in terms of the concept under investigation, i.e. the assessment in the pre-literacy period, rather than in terms of persons. The teachers were interviewed using the following tentative set of questions:

1) Do you assess your pupils?

2) What kind of tests/instruments do you use?

3) Do you follow set criteria when you assess your pupils?

4) In your opinion, what is the purpose of assessment in the pre-literacy period?

The manner of data collection differed, as we tried to accommodate the busy schedules of the participants. The participants were interviewed individually and depending on their preference by means of either face-to-face or electronic communication. The research was conducted in May 2015.

\section{PRIVATE SCHOOLS}

As opposed to primary schools in Serbia, in private schools assessment is not a school-based requirement, which means that the official requirements coming from school administration differ to a great extent. There is no legal framework that regulates private schools, no standards or accreditations, so the way private schools in Serbia function differs immensely from one situation to another. This is also reflected in the field of assessment of very young learners, as the results of the interviews have shown.

Hence, all of the teachers from private schools who participated in the research claim that they regularly assess their pupils' knowledge. It is clear from their answers that they use a variety of means to keep track of the pupils' progress and some of the ways of assess- 
ing English competence in the pre-literacy period are the following:

- flash cards: pupils look at the picture on the flash card and name the object;

- flash cards: the teacher says a word and the pupil chooses a flash card with the picture that represents the word;

- the teacher says a word and the pupil points to the object;

- drawing dictation: the teacher dictates and the pupil either draws the picture or circles the picture of an object;

- role-playing;

- the play at the end of the school year.

The answers that the teachers have provided fall both into formative and summative assessment, but one of the major problems noticed in this context is the lack of clear descriptors which the teachers can rely on when assessing the pupils' English language competence. Namely, although the teachers who participated in the research have listed several extremely valid areas in which they assess their pupils, e.g. speaking, fluency, motivation, behavior, participation, there are no clearly defined criteria that the teachers can rely on. What is most often heard is that the pupils' competence is assessed as "being able to tackle more complex structures" or not being able to do that. Their behavior is classified as "interested in classroom activities" or "disinterested in classroom activities". Although this sounds like a solid foundation for a clear assessment grid which would be helpful for a variety of classroom segments, there is no systematic application or elaboration of such a framework.

Besides the fact that assessment provides teachers with the necessary information in terms of individual development and progress of children, it is also useful as a source of feedback for teaching and learning. The teachers from private schools who participated in the research all claimed that they relied on the information from assessment to further improve their teaching and the pupils' learning. This implies the diagnostic role of assessment, which reveals problematic areas and helps the teacher focus on what needs to be further explained, repeated, practiced, etc. This falls in line with one of the basic principles of working with young learners and that is the recycling of material, which needs to be done frequently and rhythmically in order for linguistic units to be stored in the long-term memory. 


\section{STATE SCHOOLS}

Unlike private schools in Serbia, the classes in state schools are strictly regulated and controlled by the Ministry of Education, Science and Technological Development of the Republic of Serbia. All classes are taught according to the curricula adopted at the national level, but there is also a certain degree of freedom that the teachers have. Namely, they can choose which coursebook they will use as long as it is accredited by the Ministry (the process of accreditation implies a full compliance with a set of standards, which also include the curriculum for each of the subjects). The standards prescribed by the Ministry on the national level regulate assessment to a certain degree, but, as the teachers' answers have shown, the guidelines and instructions are far from clear.

All of the teachers from primary schools who participated in the research teach both in the first and second grades of primary school and the ways they described assessment of pupils in the first and the second grade differ. Namely, assessment in the first grade completely belongs to the pre-literacy stage and the teachers therefore rely on pictures, flash cards, classroom objects, like the teachers from private schools. The manner of assessment is very similar:

- flash cards: pupils look at the picture on the flash card and name the object;

- flash cards: the teacher says a word and the pupil chooses a flash card with the picture that represents the word;

- the teacher says a word and the pupil points to the object;

- drawing dictation: the teacher dictates and the pupil either draws the picture or circles the picture of an object;

- role-playing.

The teachers either use pen-and-paper tests from the teacher's books or they make the tests themselves. Furthermore, the teachers observe the pupils while carrying out instructions and assess their performance. Unlike the teachers from private schools, the teachers in state schools (as of 2016) have a pre-defined set of criteria to rely on when assessing the knowledge and participation of pupils because the Ministry has introduced new student log-books with the following rubrics: 
1) progress less than expected;

2) progress is stable but slow;

3) progress is at the expected level;

4) progress is above the expected level.

In addition, there is also a three-point scale to assess the pupils' participation in classroom activities:

1) the pupil is engaged to a lesser extent;

2) the pupil is occasionally engaged;

3) the pupil is fully engaged.

According to the teachers, this is a great aid in comparison with the situation in the previous period, but some of the teachers are still not completely sure how to utilize these two scales and what kind of knowledge and behavior falls into which category. For that reason, teachers in some schools work with their colleagues and the school principal in defining a closer set of criteria and descriptors in order to be able to assess their pupils in an objective and impartial manner. All in all, we can conclude that state school teachers use both formative and summative assessment techniques in the first grade, which is to some extent regulated by the Ministry, but there is still a lot of room for improvement.

When it comes to the assessment in the second grade of primary schools, it can be noticed that all of the teachers are gradually introducing assessment based on literacy, which is in line with the syllabus of the Serbian language classes, where the Latin alphabet is learnt in the second semester of the second grade. More specifically, in addition to the previously described types of tasks, the teachers are asking of their pupils to recognize certain words and match them to pictures and not much more than that. Active writing in English is present to a much smaller extent.

In terms of using the results of assessment for the improvement of teaching and learning, most of the teachers agree on the usefulness of the information that assessment provides in diagnosing weak areas. The teachers then rely on what they discover when assessing their pupils in order to repeat and further explain parts of the syllabus that the pupils have not mastered. In the words of several teachers, it is not possible to continue teaching new units if old ones have not been learnt well. Some teachers also note that in the first two grades of primary school there is enough time to go back and deal with problematic areas, to repeat and make sure all 
the pupils have learnt what they were supposed to learn in their English class.

\section{DISCUSSION}

When comparing the assessment of pre-literacy pupils in private and state schools, it can be said that there are many similarities: both groups of teachers resort both to summative and formative assessment; they both use observations and pen-and-paper tests that they make or that they copy from the teacher's books; they both use assessment as feedback to teaching and learning. On the other hand, there are some differences as well. Namely, assessment in private schools is not an institutional requirement and, consequently, does not rely on a firmly defined set of principles. In contrast to that, the Ministry of Education, Science and Technological Development of the Republic of Serbia has made a first step towards defining criteria for the descriptive assessment of young learners, even though these criteria are still not fully elaborated. In any case, the teachers are required to use them and they resort to what they have at their disposal to make these criteria clearer and easier to use.

\section{PEDAGOGICAL IMPLICATIONS}

In the final segment in this paper we intend to present a possible solution for the situation diagnosed in the research, namely the lack of a clearly defined set of criteria which can be used in continuous formative assessment of pupils in the pre-literacy period. Since it has been established that observation is one of the best and most appropriate approaches to the assessment of pre-literacy students, primarily because it does not disrupt the teaching and learning process, it provides helpful feedback to inform learning and teaching, and because it can cover a variety of classroom activities and other indicators of progress in foreign language acquisition, it is a highly recommended instrument in working with very young learners. The solution lies in the teacher's custom-made assessment rubric, where the categories are based on the competences that children in this age group already possess. 
The example presented below (see Table $1^{3}$ ) is the result of the authors' cooperation with an MA student and it includes the following categories in observation:

- listening

- speaking

- vocabulary

- motivation

- participation

- social English

The observation grid works in the following way: the teacher uses the chart as a reference list (similar to the CEFR) and after each class he/she can note details on the behaviour, performance and progress of each child in the group. The grid covers all relevant aspects of foreign language acquisition in the pre-literacy period and this kind of an approach to assessment provides the teacher with a detailed view of every child in the class as well as the way their knowledge, participation and motivation develop over time. This chart is not just a tool for assessment, but also a tool for diagnosing possible problems.

\begin{tabular}{|c|l|l|l|}
\hline \multicolumn{1}{|c|}{ VERY GOOD } & \multicolumn{1}{c|}{ GOOD } & \multicolumn{1}{c|}{ BAD } \\
\hline LISTENING & $\begin{array}{l}\text { understands simple } \\
\text { instructions; } \\
\text { listens and points to } \\
\text { the picture with no } \\
\text { help; } \\
\text { listens and draws/ } \\
\text { colors pictures inde- } \\
\text { pendently and se- } \\
\text { quences pictures un- } \\
\text { aided }\end{array}$ & $\begin{array}{l}\text { needs help to under- } \\
\text { stand simple instruc- } \\
\text { tions; } \\
\text { has some difficulty in } \\
\text { listening and pointing } \\
\text { tothe picture, drawing, } \\
\text { coloring and sequenc- } \\
\text { ing pictures }\end{array}$ & $\begin{array}{l}\text { cannot understand } \\
\text { simple instructions; } \\
\text { cannot listen and point } \\
\text { to the picture, draw } \\
\text { and color a picture; } \\
\text { cannot sequence pic- } \\
\text { tures }\end{array}$ \\
\hline
\end{tabular}

TABLE 1: OBSERVATION GRID FOR VERY YOUNG LEARNERS

3 This observation grid was made in cooperation with Jovana Dodić, an MA student at the Department of English Studies, Faculty of Philosophy, Novi Sad, as part of her MA thesis project. 


\begin{tabular}{|c|c|c|c|}
\hline SPEAKING & $\begin{array}{l}\text { speaks using the ap- } \\
\text { propriate vocabu- } \\
\text { lary; } \\
\text { asks and answers } \\
\text { questions using sim- } \\
\text { ple, learned phrases; } \\
\text { sings songs; } \\
\text { pronounces words } \\
\text { well }\end{array}$ & $\begin{array}{l}\text { speaks with some mis- } \\
\text { takes; } \\
\text { sings songs with some } \\
\text { difficulty; } \\
\text { cannot ask and answer } \\
\text { questions using } \\
\text { learned phrases with- } \\
\text { out help; } \\
\text { pronounces with diffi- } \\
\text { culty }\end{array}$ & $\begin{array}{l}\text { does not want to speak; } \\
\text { his/her speech is im- } \\
\text { possible to understand; } \\
\text { cannot use learned ex- } \\
\text { pressions to ask and } \\
\text { answer questions; } \\
\text { cannot pronounce } \\
\text { words or sing songs }\end{array}$ \\
\hline VOCABULARY & $\begin{array}{l}\text { recognizes spoken } \\
\text { vocabulary with or } \\
\text { without the use of } \\
\text { picture cards; } \\
\text { uses and repeats new } \\
\text { vocabulary; } \\
\text { shows understanding } \\
\text { of pronounced or } \\
\text { sung words with TPR }\end{array}$ & $\begin{array}{l}\text { has difficulty in recog- } \\
\text { nizing spoken vocabu- } \\
\text { lary with or without } \\
\text { the use of flashcards; } \\
\text { needs help to repeat } \\
\text { and use new vocabu- } \\
\text { lary; } \\
\text { makes mistakes in } \\
\text { matching words with } \\
\text { TPR }\end{array}$ & $\begin{array}{l}\text { cannot recognize vo- } \\
\text { cabulary with or with- } \\
\text { out the use of flash- } \\
\text { cards; } \\
\text { cannot use or repeat } \\
\text { new vocabulary; } \\
\text { is not able to perform } \\
\text { pronounced or sung } \\
\text { words }\end{array}$ \\
\hline MOTIVATION & $\begin{array}{l}\text { always interested in } \\
\text { doing various activi- } \\
\text { ties; } \\
\text { willing to learn more } \\
\text { English }\end{array}$ & $\begin{array}{l}\text { interested only in do- } \\
\text { ing activities of his/her } \\
\text { interest; } \\
\text { willing to learn English } \\
\text { to some extent }\end{array}$ & $\begin{array}{l}\text { does not show interest } \\
\text { in doing activities; } \\
\text { unwilling to learn more } \\
\text { English }\end{array}$ \\
\hline PARTICIPATION & $\begin{array}{l}\text { participates in all ac- } \\
\text { tivities: } \\
\text { cooperates with all } \\
\text { members of the class; } \\
\text { works well in pairs/ } \\
\text { groups }\end{array}$ & $\begin{array}{l}\text { only participates in } \\
\text { some activities; } \\
\text { cooperates with some } \\
\text { members of the class; } \\
\text { sometimes works well } \\
\text { in pairs/groups }\end{array}$ & $\begin{array}{l}\text { does not participate in } \\
\text { activities; } \\
\text { does not cooperate } \\
\text { with members of the } \\
\text { class; } \\
\text { works well inde- } \\
\text { pendently }\end{array}$ \\
\hline SOCIAL ENGLISH & $\begin{array}{l}\text { uses new vocabulary } \\
\text { in different situa- } \\
\text { tions and with other } \\
\text { people apart from } \\
\text { the classroom }\end{array}$ & $\begin{array}{l}\text { sometimes uses new } \\
\text { words and phrases in } \\
\text { situations with par- } \\
\text { ents, friends etc. }\end{array}$ & $\begin{array}{l}\text { does not use the for- } \\
\text { eign language outside } \\
\text { the classroom }\end{array}$ \\
\hline
\end{tabular}

TABLE 1: OBSERVATION GRID FOR VERY YOUNG LEARNERS

What is new about this grid in comparison with others that are found in the literature is that it contains sections dealing with motivation and affective factors, as well as social skills. These two cate- 
gories provide additional dimensions in assessment which are important for both the teacher and the parents.

CONCLUSION English language classes in the pre-literacy period should not avoid assessment because it not only provides information on individual pupils' progress but also serves teaching by making the next teaching event more effective. This paper attempted to present the situation in primary and private schools in Serbia with respect to the assessment of very young learners who still cannot read or write. It was established that assessment does happen in a variety of ways, but the impression is that teachers do not opt very often for performance-based assessment by observation because it is more difficult and requires much more effort. Their choice is understandable if we have in mind that many classes in primary schools have around 30 pupils, which poses a considerable challenge when assessment by means of observation is to be performed. However, given the crucial advantages provided by the continuous formative assessment, it is our belief that it will be the pupils in large classes who will benefit most from this type of assessment. One of the possible strategies for performing observations in large classes would be to designate a certain number of pupils who would be observed and assessed during a single lesson. If conducted in a systematic way, assessment by observation would help individualize instruction, provide invaluable feedback and support learning the foreign language the aim of which is to facilitate the improvement of pupils' cognitive, affective and social competences.

Alderson, J. C. et al. (1995). Language test construction and evaluation. Cambridge: Cambridge University Press.

Cameron, L. (2001). Teaching languages to young learners. Cambridge: Cambridge University Press.

Corbin, J., \& Strauss, A. (1990). Grounded theory research: procedures, canons, and evaluative criteria. Qualitative sociology 13/1: 3-21.

Gordon, T. (2007). Teaching young learners a second language. Westport, London: Praeger.

Henning, G. (1987). A guide to language testing. Cambridge, Mass.: Newbury House.

Hughes, A. (1989). Testing for language teachers. Cambridge: Cambridge University Press. 
Prodromou, L. (1995). The backwash effect: from testing to teaching. ELT Journal 49/1: 13-25.

Shaaban, K. (2001). Assessment of young learners. Forum 39/4: 16-25.

Shohamy, E. (1995). Performance assessment in language testing. Annual Review of Applied Linguistics 15: 188-211.

Smith, K. (1997). Assessing and testing young learners: Can we? Should we? In: D. Allen (Ed.), Entry points: Papers from a Symposium of the Research, Testing, and Young Learners Special Interest Groups. Whitstable: IATEFL.

Taras, M. (2005). Assessment - summative and formative - some theoretical reflections. British Journal of Educational Studies 53/4: 466-478.

Yildirim, R. and Orsdemir, E. (2013). Performance Tasks as Alternative Assessment for Young EFL Learners: Does Practice Match the Curriculum Proposal? International Online Journal of Educational Sciences 5/3: 562-574.

БИљАНА Б. РАДИЋ БОЈАНИЋ

ЈАГОДА П. ТОПАЛОВ

УНИВЕРЗИТЕТ У НОВОМ САДУ

ФИЛОЗОФСКИ ФАКУЛТЕТ

ОДСЕК ЗА АНГЛИСТИКУ

РЕЗИМЕ

\author{
ОЦЕЊИВАЮЕ УЧЕНИКА НА РАНОМ УЗРАСТУ \\ ПРЕ ФОРМАЛНЕ ПИСМЕНОСТИ У СРБИЈИ
}

Услед чињенице што је енглески језик обавезан предмет од првог разреда у школама у Србији, ученици у прва два разреда основне школе енглески уче пре формалног описмењавања, с обзиром на то што латиницу науче тек у другом полугодишту другог разреда. Циљ рада јесте да испита под којим условима се ученици на овом узрасту оцењују на часовима енглеског језика. У раду се испитују следећа четири истраживачка питања: 1) да ли се у школама у србији уопште спроводи оцењивање знања енглеског језика код ученика на раном узрасту, који још увек нису формално писмени, 2) уколико се такво оцењивање спроводи, који се инструменти користе и који се критеријуми том приликом примењују, 3) шта је сврха оцењивања код ученика који нису формално писмени, те 4) да ли постоје разлике између државних и приватних школа по питању начина и сврхе оцењивања знања. У ту сврху спроведено је квалитативно истраживање путем неформалног интервјуа са 15 наставника из државних и 
приватних школа. Резултати истраживања најпре показују да се у оба институционална контекста користи како сумативно тако и формативно оцењивање; такође, наставници и из приватних и из државних школа користе методу посматрања, или тестове које сами праве или узимају из приручника за наставнике; коначно, у оба контекста наставници користе резултате оцењивања као повратне информације које им затим служе да побољшају наставу. Резултати такође показују да постоје разлике између наставника у приватним и државним школама по питању оцењивања ученика. Разлике су у највећој мери последица непостојања институционализоване обавезе оцењивања у приватним школама, те се, самим тим, у приватним школама оцењивање не спроводи према строго дефинисаним принципима и мерилима. Насупрот приватним школама, Министарство образовања, науке и технолошког развоја Републике Србије начинило је први корак ка дефинисању критеријума за дескриптивно оцењивање ученика на раном узрасту, иако ти критеријуми нису још увек у потпуности развијени. Наставници у државним школама, упркос томе, имају обавезу да ове критеријуме користе, и често посежу ка различитим средствима како би олакшали употребу критеријума приликом оцењивања. У последњем делу рад се усмерава ка педагошким импликацијама добијених резултата истраживања и нуди решење засновано на способностима које деца на овом узрасту већ поседују, као и на наставним аспектима, али и аспектима учења који умногоме доприносе развоју знања енглеског језика код деце.

КљУчнЕ РЕчи: ученици на раном узрасту, узраст пре формалне писмености, оцењивање, формативно оцењивање, сумативно оцењивање.

Овај чланак је објављен и дистрибуира се под лиценцом Creative Commons

Ауторство-Некомерцијално Међународна 4.0 (СС BY-NC 4.0 |

https://creativecommons.org/licenses/by-nc/4.0/).

This paper is published and distributed under the terms and conditions of the Creative Commons Attribution-NonCommercial International 4.0 licence (CC BY-NC 4.0 | https://creativecommons.org/licenses/by-nc/4.0/). 